ISSN 1392-3196 / e-ISSN 2335-8947

Zemdirbyste-Agriculture, vol. 108, No. 1 (2021), p. 51-56

DOI 10.13080/z-a.2021.108.007

\title{
Comparison of sugars, lipids and phenolics content in the grains of organically and conventionally grown soybean in Serbia
}

\author{
Jelena M. GOLIJAN ${ }^{1}$, Danijel D. MILINČIĆ ${ }^{1}$, Radivoj B. PETRONIJEVIĆ ${ }^{2}$, Mirjana B. PEŠIĆ ${ }^{1}$, \\ Sladjana P. STANOJEVIĆ ${ }^{1}$, Miroljub B. BARAĆ ${ }^{1}$, Slavoljub LEKIĆ ${ }^{1}$, Aleksandar Ž. KOSTIĆ ${ }^{1}$ \\ ${ }^{1}$ University of Belgrade, Faculty of Agriculture \\ Nemanjina 6, 11080 Belgrade, Serbia \\ E-mail: akostic@agrif.bg.ac.rs \\ ${ }^{2}$ Institute of Meat Hygiene and Technology \\ Kaćanskog 13, 11000 Belgrade, Serbia
}

\begin{abstract}
The aim of the current study was to determine the content of several primary metabolites: total soluble sugars, starch and lipids, soluble sugars, fatty acids and triacylglycerols profile, and secondary metabolites: total phenolics and flavonoids, in the grains of soybean (Glycine max (L.) Merr.) cultivar 'Kaća'. Additionally, grain antioxidant properties were assessed using $\mathrm{ABTS}^{+}$scavenging capacity and ferric reducing power (FRP) assays. Soybean was developed and grown in Serbia under two cultivation systems (conventional and organic) during two growing seasons (2016 and 2017). In both growing seasons and cultivation systems, soybean grains were characterised by reduced lipid content (8.16-14.34\%) and as an excellent source of polyunsaturated fatty acids. Triacylglycerols (TAGs) with 44 equivalent carbon numbers (ECN44) represented the main fraction (30.95-32.79\%) followed by ECN46 TAGs (23.27-26.36\%). Low total soluble sugars (2.36-11.51\%) content was determined. High-performance liquid chromatography (HPLC) analysis revealed a significant prevalence of non-reducing disaccharides (1.41-6.57\%) among the individual sugars. Soybean grains were proved as a good source of phenolic (2493.9-4419.5 mg kg-1) and flavonoid (292.7-500.9 mg kg correlations were observed between both cultivation systems and growing seasons indicating no clear differences for the majority of analysed parameters. All examined extracts possessed a significant ability (27.6-38.2\%) to neutralize ABTS ${ }^{+}$radicals, while in the case of FRP assay a significant ability for iron ions $\left(\mathrm{Fe}^{3+}\right)$ reduction was recorded for the samples from the second growing season.
\end{abstract}

Key words: antioxidant activity, fatty acids, Glycine max, phenolic compounds, sugars, triacylglycerols.

\section{Introduction}

Soybean (Glycine max (L.) Merr.) is one of the most cultivated pulses all around the world. Historical data link its origin to North and Central China $(4,000$ to 5,000 years ago), while it first appeared in Europe in 1712 (Liu, 1997). This is an important plant, whose grains are widely used in human and animal diet, because they contain considerable amount of proteins (Peiretti et al., 2019), and some other phytonutrients including different phenolics, phytosterols, etc. (Prabakaran et al., 2018). Moreover, some components with potentially negative impact on human health such as saponins are present in the soybean grains (Kim et al., 2013). In addition, it is one of the most important plants used for industrial production of vegetable oils (Aguirrezábal et al., 2015).

Two predominant components in the soybean grains are proteins and lipids (oils), which build up more than $60 \%$ of the total mass. Among others, sugars (about 35\%) and minerals (about 5\%) are also significantly represented. The main part of the proteins and oils is located in the cotyledons, while in the hull these components are actually represented as minority (Liu, 1997). In this sense, the non-hulled soybean grains can be a good source of different secondary plant metabolites, i.e. phenolic acids or flavonoids, which are mostly responsible for the antioxidant potential of the plant material (Kim et al., 2016; Peiretti et al., 2019).

Besides, there are differences between the soybean cultivars depending on whether they are developed to feed animals or humans. It is known that there exist soybean cultivars (food bean cultivars), which are protein-rich / lipid-low cultivars, grown primarily for direct human food application, and that have been developed in the Western civilization during the last few decades (Liu, 1997).

Chemical composition of the plant can be significantly influenced by the growing conditions (Aguirrezábal et al., 2015). Among them, the application of mineral fertilisers (conventional growing system) or fertiliser free conditions (organic growing system) have become important in agriculture during the last decades. According to some literature data (Sudarić et al., 2019), conventional tillage and foliar application of nitrogen $(\mathrm{N}-)$ fertilisers during seed filling can increase the protein content in soybean, while no-tillage and inadequate $\mathrm{N}$-fertiliser treatment will decrease the oil content. Due to lower availability of $\mathrm{N}$ during organic growing process, plants synthetize higher quantities of secondary metabolites such as phenolics (Rembialkowska, 2007). In addition, genetics (Hou et al., $2009 \mathrm{a} ; \mathrm{b}$ ) and plant 
life cycle (Peiretti et al., 2019) can also have significant influence on the content of different phytochemicals. Although there is information about the chemistry of the soybean grains for different cultivars all around the world (Saldivar et al., 2011; Teixeira-Guedes et al., 2019; Wijewardana et al., 2019) including Serbia (Žilić et al., 2015; Kresović et al., 2017), there is still a paucity of research evidence for some local cultivars.

In this regard, the aim of this study was to characterize and determine the content of several important nutrients (lipids and sugars) and phytochemicals (phenolics and flavonoids), and to specify fatty acid, triacylglycerols and sugar profiles for the grain of soybean cultivar 'Kaća' developed and grown in Serbia under two different cultivation systems - conventional and organic. This cultivar is important since it has been developed for direct human food. Also, antioxidant properties of the examined soybean grains were assessed with two standard methods $-\mathrm{ABTS}^{\bullet+}$ scavenging capacity and ferric reducing power (FRP).

\section{Materials and methods}

Sampling and extraction procedures. The grain samples of the local soybean (Glycine max (L.) Merr.) cultivar 'Kaća' were obtained from the Institute of Field and Vegetable Crops experimental field at Bački Petrovac, Serbia during two growing seasons, 2016 and 2017. The soybean was sown in April 2016 and 2017 in Calcic Chernozem (Anoaric, Loamic, Pachic) (WRB, 2014). In the conventional cultivation system, NPK fertiliser $16: 16: 16$ was added in the amount of $120 \mathrm{~kg} \mathrm{ha}^{-1}$, while in the organic system fertilisation was not applied. Herbicides (a.i. imazamox and quizalofop-P-tefuryl) were used for weeds management in the conventional cultivation system, while manual ploughing and inter-row cultivation were utilized in the organic system. The harvesting was carried out manually during September in 2016 and 2017 at the stage of full grain maturity. The average air temperature was $19.4^{\circ} \mathrm{C}$ (growing season 2016) and $20.1^{\circ} \mathrm{C}$ (growing season 2017). The average rainfall during 2016 was $439.7 \mathrm{~mm}$, while during 2017 it was $218.9 \mathrm{~mm}$.

Whole grains were ground and placed in vacuum bags and kept in a dark and cold place (at $4^{\circ} \mathrm{C}$ temperature) until further analysis. All extractions and analyses were performed successively in 2016 and 2017. In total, four samples were prepared: the organically grown grains from 2016 and 2017 as well as the conventionally grown grains from the same years.

Lipid extraction. Extraction of the total lipids from the whole milled grains of the conventionally and organically grown soybean was performed for 10 minutes according to the methodology described in Golijan et al. (2019) by using $n$-hexane/isopropanol mixture $(3: 2, \mathrm{v} / \mathrm{v})$. Extraction was repeated twice. The obtained extracts were merged, and the solvent was evaporated in inert atmosphere at $50^{\circ} \mathrm{C}$ temperature by using the nitrogen (N) stream. The dry residue was measured, and the total lipids content was determined and expressed as $\%$, i.e. $\mathrm{g} 100 \mathrm{~g}^{-1}$ dry weight (DW) of sample.

Extraction of total soluble sugars and starch. For further analysis, $0.5 \mathrm{~g}$ of grain samples were extracted with $10 \mathrm{~mL}$ of $80 \%$ methanol $\left(\mathrm{CH}_{3} \mathrm{OH}\right)$ for 45 minutes at a room temperature. The extraction procedure was repeated three times. All supernatants were merged and diluted with distilled water up to $50 \mathrm{~mL}$. After this, the solvent was evaporated under vacuum, and the final volume of the samples was set to $10 \mathrm{~mL}$. The total soluble sugar fractions were prepared in this way. The final solid residues left after the previous extractions were processed according to the modified Laware (2015) method in order to obtain starch fractions. For this purpose, the digestion system was prepared by mixing $10 \mathrm{~mL}$ of perchloric acid $(52 \%)$ and $7.7 \mathrm{~mL}$ of distilled water. Grain residues were immersed in the digestion fluid for $1 \mathrm{~h}$ in an ice bath. The extraction procedure was repeated, and the obtained supernatants were merged and neutralized with adequate volume of $12 \mathrm{M}$ sodium hydroxide $(\mathrm{NaOH})$ and saturated sodium carbonate $\left(\mathrm{Na}_{2} \mathrm{CO}_{3}\right)$ solutions. The final volume of extracts was set to $50 \mathrm{~mL}$ with distilled water.

Extraction of individual soluble sugars. The amount of $5 \mathrm{~g}$ of grain flour was weighed and mixed with approximately $40 \mathrm{~mL}$ of deionized water. The mixture was heated to boiling, cooled down and transferred to a $100 \mathrm{~mL}$ volumetric flask and filled with deionized water to the mark.

Extraction of total phenolics. For further analysis, $1 \mathrm{~g}$ of grain samples was mixed and shook with $10 \mathrm{~mL}$ of $80 \% \mathrm{CH}_{3} \mathrm{OH}$ for $1 \mathrm{~h}$ at a room temperature in a dark place. The extraction procedure was repeated three times in order to increase the yield of the phenolic fraction. The supernatants were merged, the solvent was evaporated under vacuum and the final volume of extracts was set to $10 \mathrm{~mL}$ with $80 \% \mathrm{CH}_{3} \mathrm{OH}$. The free phenolics fraction was prepared following this method. In order to obtain the bound phenolics fraction solid residue, the remainder of previous extraction was digested with $40 \mathrm{~mL} \mathrm{NaOH}(2 \mathrm{M})$ for 4 hours. An adequate volume of hydrochloric acid $(\mathrm{HCl})$ solution $(12 \mathrm{M})$ was added in order to set the final solution $\mathrm{pH}$ to 2 . Then, the bound phenolics were extracted with ethyl-acetate $(10 \mathrm{~mL})$ three times and separated from the rest of aqueous fraction. All ethyl-acetate fractions were mixed and evaporated under vacuum. The solid residue was re-dissolved in $10 \mathrm{~mL}$ of $80 \%$ CH OH (Kováčová, Malinová, 2007). The obtained extracts were used for the determination of the content of free and bound phenolics and flavonoids as well as for the determination of the antioxidant activity of the soybean grain samples through several tests.

Analytical procedures. Determination of fatty acids and triacylglycerols (TAGs) content. The fatty acid and TAG content was determined according to the method described in Golijan et al. (2019). The obtained results were expressed as mass \% of total fatty acids per DW of sample.

Determination of the total soluble sugars and starch content. For this analysis, prepared and dilluted methanolic extracts were used by applying the standard anthrone method (Frølund et al., 1996). The obtained results are expressed as $\%$ of glucose $\left(\mathrm{g} 100 \mathrm{~g}^{-1}\right)$ DW of sample.

Determination of individual soluble sugars content. High performanceliquidchromatography(HPLC) method with refractive index (RI) detection was applied for sugar composition analysis. Chromatographic system consisted of an isocratic pump 1515, an autosampler 717 , a column heater with a temperature control module and a refractive index detector 2414 (Waters, USA). Mobile phase composition was water:acetonitrile $20: 80 \mathrm{v} / \mathrm{v}$ with the flow rate of $2 \mathrm{ml} \mathrm{min}^{-1}$. Sugar separation was achieved on the Omega Sugar column (Phenomenex, USA). The column and detector temperatures were set to $40^{\circ} \mathrm{C}$. Sugar extracts were filtered through a filter disc pore size $0.45 \mu \mathrm{m}$. The sample injection volume was $10 \mu \mathrm{l}$. The obtained results are expressed as $\%\left(\mathrm{~g} 100 \mathrm{~g}^{-1}\right)$ of total soluble sugars.

Determination of free and bound phenolics content. Standard Folin-Ciocalteau method (Singleton et al., 1999) was used. The obtained results for the content of polyphenols (free and bound) are expressed as $\mathrm{mg}$ of ferullic acid equivalent (FAE) per $\mathrm{kg}$ DW of sample.

Determination of free and bound flavonoids content. For this purpose, aluminium chloride method described by Lin and Harnly (2007) was applied. The obtained values of free and bound flavonoids are expressed as mg of quercetin equivalent (QE) per $\mathrm{kg} \mathrm{DW}$ of sample.

Determination of $A B T S^{++}$scavenging capacity.

The ability of methanolic extracts of soybean grains to quench this radical was determined using the method developed by Serpen et al. (2007) and expressed as $\%$ of inhibition of $\mathrm{ABTS}^{+}\left(2,2^{\prime}\right.$-azino-bis(3ethylbenzothiazoline-6-sulfonic acid) radical cation. 
Determination of ferric reducing power (FRP). This antioxidant grain characteristic was examined at the absorbance of $700 \mathrm{~nm}$ according to the methodology described by Sedej et al. (2010). The resulting ability for reduction of iron ions $\left(\mathrm{Fe}^{3+}\right)$ is expressed as $\mathrm{mg}$ of butylated hydroxytoluene (BHT) equivalent per kg DW of sample by using the calibration curve obtained from BHT as the standard.

Statistical analysis. Results of all analyses were expressed as the mean of three measurments \pm standard deviation (SD), while the significance of differences between the means $(p<0.05)$ was determined by using Tukey's test, software Statistica, version 8.0 (StatSoft Inc., USA). The correlation analysis between the various antioxidant assays and the nutrient and phytochemical content, i.e. between type of soybean production for two growning seasons, were performed by calculating Pearson's correlation coefficient $(r)$. Correlations at $p<0.05$ were considered significant. Bland-Altman plot analysis is often used in the literature to assess the consistency of two competing data sources. Therefore, this test was used for comparison of two cultivation systems and two growing seasons of soybean production (95\% limits of agreement as the mean difference) via software GraphPad Prism ${ }^{\circledR}$, version 6.01 (GraphPad Software Inc., USA).

\section{Results and discussion}

Content of sugars, fatty acids and triacylglycerols (TAGs). Since the soybean is recognized as one of the most used industrial plants for vegetable oil production (Aguirrezábal et al., 2015), the first part of this experiment was conducted in order to determine the content and the profile of several lipid components. The results of the analysis of the soybean grain lipid fractions are given in Table 1.

Table 1. Content (\%) of total lipids, fatty acids and triacylglycerols in soybean grains

\begin{tabular}{|c|c|c|c|c|}
\hline Year & \multicolumn{2}{|c|}{2016} & \multicolumn{2}{|c|}{2017} \\
\hline Cultivation system & Organic & Conventional & Organic & Conventional \\
\hline \multicolumn{5}{|c|}{ Total lipids } \\
\hline & $9.42 \pm 0.5 \mathrm{a}$ & $8.16 \pm 0.18 b$ & $14.34 \pm 0.13 \mathrm{c}$ & $12.69 \pm 0.13 \mathrm{~d}$ \\
\hline \multicolumn{5}{|c|}{ Fatty acids } \\
\hline C14:0 & $0.72 \pm 0.03 \mathrm{a}$ & $0.72 \pm 0.02 \mathrm{a}$ & $0.06 \pm 0.005 \mathrm{~b}$ & $0.06 \pm 0.008 \mathrm{~b}$ \\
\hline C16:0 & $10.94 \pm 0.25 \mathrm{a}$ & $10.93 \pm 0.14 \mathrm{a}$ & $9.22 \pm 0.21 \mathrm{~b}$ & $9.41 \pm 0.39 \mathrm{~b}$ \\
\hline $\begin{array}{l}\text { C16:1 } \\
\text { C18:0 }\end{array}$ & $\begin{array}{c}0.07 \pm 0.001 \mathrm{ab} \\
449 \pm 0.1 \mathrm{a}\end{array}$ & $\begin{array}{l}0.08 \pm 0.002 \mathrm{a} \\
5.04 \pm 0.07 \mathrm{ab}\end{array}$ & $\begin{array}{l}0.06 \pm 0.008 \mathrm{~b} \\
468 \pm 0.68 \mathrm{ab}\end{array}$ & $0.07 \pm 0.009 \mathrm{ab}$ \\
\hline C18:1n-9 & $24.89 \pm 0.2 \mathrm{a}$ & $24.15 \pm 0.46 \mathrm{a}$ & $33.08 \pm 0.32 \mathrm{~b}$ & $33.69 \pm 1.71 \mathrm{~b}$ \\
\hline C18:2n-6 & $52.14 \pm 1.03 \mathrm{a}$ & $51.65 \pm 1.06 \mathrm{a}$ & $48.23 \pm 1.24 b$ & $46.5 \pm 0.99 \mathrm{~b}$ \\
\hline C20:0 & $0.37 \pm 0.01 \mathrm{a}$ & $0.51 \pm 0.01 \mathrm{~b}$ & $0.44 \pm 0.03 \mathrm{c}$ & $0.51 \pm 0.035 \mathrm{~b}$ \\
\hline C18:3n-3 & $5.81 \pm 0.1 \mathrm{a}$ & $6.26 \pm 0.08 b$ & $3.69 \pm 0.26 \mathrm{c}$ & $3.84 \pm 0.096 \mathrm{c}$ \\
\hline $\begin{array}{l}\text { C20:1 } \\
\text { C22:0 }\end{array}$ & $0.17 \pm 0.01 \mathrm{a}$ & $0.17 \pm 0.01 \mathrm{a}$ & $0.04 \pm 0.005 \mathrm{~b}$ & $0.03 \pm 0.005 \mathrm{~b}$ \\
\hline SFA & $\begin{array}{c}0.4 \pm 0.02 \mathrm{a} \\
16.92 \pm 0.42 \mathrm{ac}\end{array}$ & $\begin{array}{c}0.51 \pm 0.02 \mathrm{~b} \\
17.71 \pm 0.26 \mathrm{a}\end{array}$ & $14.75 \pm 0.58 \mathrm{~b}$ & $\begin{array}{c}0.4 \pm 0.02 \mathrm{a} \\
15.68+0.72 \mathrm{bc}\end{array}$ \\
\hline MUFA & $25.13 \pm 0.21 \mathrm{a}$ & $24.4 \pm 0.47 \mathrm{a}$ & $33.18 \pm 0.33 \mathrm{~b}$ & $33.78 \pm 1.72 \mathrm{~b}$ \\
\hline PUFA & $57.94 \pm 1.13 \mathrm{a}$ & $57.91 \pm 1.14 \mathrm{a}$ & $51.92 \pm 1.50 \mathrm{~b}$ & $50.34 \pm 1.09$ \\
\hline \multicolumn{5}{|c|}{ Triacylglycerols } \\
\hline ECN42 & $24.28 \pm 0.36 \mathrm{a}$ & $24.31 \pm 0.42 \mathrm{a}$ & $29.00 \pm 1.12 \mathrm{~b}$ & $27.01 \pm 0.88 b$ \\
\hline ECN44 & $32.21 \pm 0.56 \mathrm{a}$ & $32.79 \pm 0.68 \mathrm{a}$ & $30.95 \pm 1.1 \mathrm{a}$ & $30.81 \pm 1.97 \mathrm{a}$ \\
\hline $\begin{array}{l}\text { ECN46 } \\
\text { FCN48 }\end{array}$ & $26.36 \pm 0.52 \mathrm{a}$ & $25.73 \pm 0.56 \mathrm{ac}$ & $23.27 \pm 0.48 b$ & $24.19 \pm 1.41 \mathrm{ab}$ \\
\hline $\begin{array}{l}\text { ECN48 } \\
\text { ECN50 }\end{array}$ & $\begin{array}{r}13.66 \pm 0.33 \mathrm{a} \\
3.49 \pm 0.1 \mathrm{a}\end{array}$ & $\begin{array}{l}13.36 \pm 0.34 \mathrm{a} \\
3.81 \pm 0.12 \mathrm{a}\end{array}$ & $13.23 \pm 0.87 \mathrm{a}$ & $\begin{array}{l}14.02 \pm 0.27 \mathrm{a} \\
3.97+0.29 \mathrm{a}\end{array}$ \\
\hline LCIVJu & 0.491 & $0.01 工$ & $3.5 J \pm 0.34 \mathrm{a}$ & $3.97 \pm 0.29 \mathrm{a}$ \\
\hline
\end{tabular}

Note. Acids: C14:0 - myristic, C16:0 - palmitic, C16:1 - palmitoleic, C18:0 - stearic, C18:1n-9 - oleic, C18:2n-6 - linoleic, C20:0 - arachidic, C18:3n-3 - linolenic, C20:1 - eicosenoic, C22:0 - behenic; fatty acids: SFA - saturated, MUFA - monounsaturated, PUFA - polyunsaturated; ECN - equivalent carbon number; values with the same letter in the same row do not significantly differ $(p<0.05)$.

As it can be seen from Table 1, the total lipids content was in the range from $8.16 \%$ to $14.34 \%$, i.e.

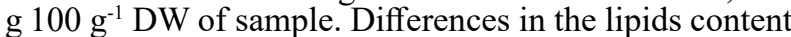
between the growing seasons may be conditioned by the differences in the growing environment. These values were lower compared to the results obtained for some other local soybean cultivars $(\sim 20 \%)$ (Kresović et al., 2017 ) or a cultivar from the USA (21-23\%) (Dornbos, Mullen, 1992). Regarding the fatty acids composition, it can be concluded that the unsaturated fatty acids are predominant components in the soybean grains with the significant prevalence of the linoleic $(46.5-52.1 \%)$ and oleic (24.1-33.7\%) acids. In addition, palmitic, linolenic and stearic acids were determined in significant quantities. For all other identified fatty acids (myristic, palmitoleic, eicosanoic, eicosenoic and docosanoic acids), it can be said that they are present in trace levels. The obtained results are in full agreement with those for the soybean cultivar 'Gnome' from the USA (Dornbos, Mullen, 1992), in the grains of which the linoleic, oleic, palmitic, stearic and linolenic acids were the main components.

In order to complete the lipids profile of the soybean grains, the content of TAGs was also determined and presented in Table 1. Based on the obtained results, it can be concluded that TAGs with 44 equivalent carbon numbers (ECN44) were in the highest portion in all the grains of the soybean $(32.2-32.8 \%)$ followed by ECN46 TAGs - 25.7-26.4\%. There were no differences between organic and conventionally grown soybean grains in TAGs share. The obtained results are in accordance with those for the cultivar 'Ika' from Croatia - ECN44, ECN46 and ECN42 TAGs were predominantly present (Jokić et al., 2010). In the case of the cultivar 'Corsoy 79' from Canada, slightly different results were found - ECN44 were followed by ECN42 and ECN46 TAGs (Jahaniaval et al., 2000).

Besides lipids, sugars are also the main components in the examined soybean grains (Table 2 ).

It can be observed that the soluble sugars content differed significantly between growing seasons and cultivation systems. The obtained results confirm the importance of growing conditions for nutrient content in the grain. The results for soluble sugars from 2016 are comparable with those for different soybean cultivars from Peru, Turkey, Uganda and Uruguay (Hou et al., 2009 b), while the results from 2017 are similar to (conventional) or slightly lower (organic) than those obtained for the low oligosaccharide cultivar from the USA (Hou et al., 2009 a).

According to the results of the HPLC analysis, the content of the total mono- and disaccharides were in the ranges from $1.65 \%$ to $3.55 \%$ (total monosaccharides) and from $1.77 \%$ to $7.19 \%$ (total disaccharides). The results for the total sugars obtained by the HPLC analysis are comparable to those recorded through the Antron spectrophotometric method (the soluble sugar content was $2.4-11.5 \%$ ). The content of non-reducing disaccharides $(4.7-6.6 \%)$ from 2016 was similar to that of sucrose in the yellow soybean grains $(\sim 6 \%)$ from Spain (Espinosa-Martos, Rupérez, 2006). In addition, it can be 
Table 2. Content (\%) of soluble sugars, mono- (pentose and hexose) and disaccharides and starch in soybean grains

\begin{tabular}{|c|c|c|c|c|}
\hline Year & \multicolumn{2}{|c|}{2016} & \multicolumn{2}{|c|}{2017} \\
\hline Cultivation system & organic & conventional & organic & conventional \\
\hline Soluble sugars & $7.19 \pm 0.36$ & $11.51 \pm 0.52$ & $2.36 \pm 0.13$ & $3.03 \pm 0.13$ \\
\hline Pentose & $1.27 \pm 0.072 \mathrm{a}$ & $1.64 \pm 0.119 \mathrm{~b}$ & $1.01 \pm 0.12 \mathrm{c}$ & $0.96 \pm 0.061 \mathrm{c}$ \\
\hline Hexose & $1.36 \pm 0.091 \mathrm{a}$ & $1.91 \pm 0.047 \mathrm{~b}$ & $0.82 \pm 0.022 \mathrm{c}$ & $0.69 \pm 0.044 \mathrm{c}$ \\
\hline Total monosaccharides & $2.63 \pm 0.16 \mathrm{a}$ & $3.55 \pm 0.17 b$ & $1.83 \pm 0.14 \mathrm{c}$ & $1.65 \pm 0.11 \mathrm{c}$ \\
\hline Non-reducing disaccharides & $4.71 \pm 0.14 \mathrm{a}$ & $6.57 \pm 0.047 \mathrm{~b}$ & $1.41 \pm 0.052 \mathrm{c}$ & $1.42 \pm 0.054 \mathrm{c}$ \\
\hline Reducing disaccharides & $0.58 \pm 0.014 \mathrm{a}$ & $0.62 \pm 0.045 \mathrm{a}$ & $0.4 \pm 0.019 \mathrm{~b}$ & $0.35 \pm 0.015 b$ \\
\hline Total disaccharides & $5.29 \pm 0.15 \mathrm{a}$ & $7.19 \pm 0.09 \mathrm{~b}$ & $1.81 \pm 0.07 \mathrm{c}$ & $1.77 \pm 0.07 \mathrm{c}$ \\
\hline Starch & $9.22 \pm 0.45$ & $6.63 \pm 0.37$ & $2.85 \pm 0.25$ & \\
\hline
\end{tabular}

Note. Values with the same letter in the same row do not significantly differ $(p<0.05)$.

noted that the non-reducing disaccharides are a prevalent component compared to the reducing ones, which agrees with the literature data (Liu, 1997).

Results for starch content in the examined grain samples from 2016 were lower compared to the data for different soybean cultivars $(10.9-11.7 \%)$ from the USA (Stevenson et al., 2006), while the results from 2017 were similar to those for some of the 17 soybean genotypes $(0.41-$ $1.34 \%)$ that are defined as high $(1.00-1.30 \%)$ or medium (0.66-0.99\%) starch lines (Dhungana et al., 2017).

Based on the data for several parameters: total lipids, fatty acids, TAGs, soluble sugars, starch and total soluble sugars composition, obtained from different cultivation systems, Bland-Altman plot analysis was conducted (Fig. 1A). In accordance with applied statistical test, all analysed data did not significantly differ $(p<0.05)$ with exception for soluble sugars (growing season 2016) and starch (growing seasons 2016 and 2017). This suggests that there are significant differences $(p<0.05)$ between cultivation systems for content of soluble sugars and starch.

Figure 1B presents comparison of results obtained for two growing seasons. The given results mean that the majority of examined parameters (listed above) did not significantly differ $(p<0.05)$ between the growing seasons except for the following parameters: the content of MUFA in organic grains, the content of soluble sugars in conventionally produced grains as well as the content of oleic acid for both cultivation systems.
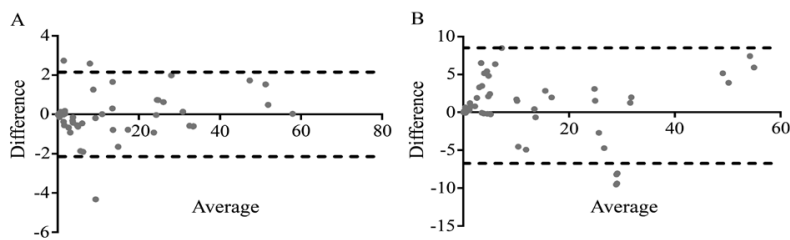

Figure 1. Bland-Altman plot analysis with limits of agreement (dashed line): two cultivation systems (organic and conventional) (A), and two growing seasons (2016 and 2017) (B) of soybean production

The obtained results of Bland-Altman plot analysis are in line with those obtained from Pearson's correlation coefficient $(r)$ (Table 3$)$. Strong positive correlations $(r=0.893-0.995)$ were observed between both cultivation systems and growing seasons.

Content of total phenolics and flavonoids. In the last few decades, there has been an increasing interest of medical and nutrition researchers in the soybean because of significant phenolic content, especially phenolic compounds (Prabakaran et al., 2018) and isoflavones, one of the numerous flavonoids subclasses (Liu, 1997) in the grains. In general, plant phenolic acids are present in two forms. Free phenolics and those conjugated with carbohydrates (glycoside form) are soluble, i.e. extractible components (Kim et al., 2016). On the other hand, a significant part of the soybean polyphenols is attached to some cell wall components forming an insoluble fraction, which must be released before determination by applying alkaline or acidic digestion. The liberation of bound phenolics is also important, if we want to allow them to manifest beneficial physiological activities in the human body (Kim et al., 2016).

In the soybean cultivar 'Kaća' grains, free phenolics present the main fraction (Fig. 2). Comparing the samples, the free phenolics content was in ranges 3425.3-4306.0 mg kg-1 FAE (growing season 2016) and 1464.0-1966.1 mg kg-1 FAE (growing season 2017), which significantly differed between the growing seasons and cultivation systems. In contrast, the bound phenolics content varied only for the organic soybean grains from 2016 (552.4 mg kg-1 FAE). In the case of flavonoids, conventionally produced grains from 2017 stood out by the free flavonoids content $\left(451.6 \mathrm{mg} \mathrm{kg}^{-1} \mathrm{QE}\right)$, while the bound flavonoids content was similar (without statistically significant differences) for both samples during the same growing season.
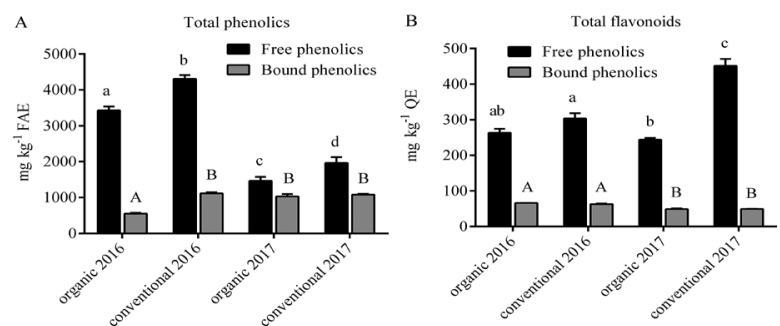

Note. Bars followed by the same lower- and upper-case letters are not significantly different $(p<0.05)$ according to Tukey's test $(\mathrm{n}=3) ; \mathrm{FAE}$ - ferulic acid equivalent, $\mathrm{QE}$ - quercetin equivalent.

Figure 2. The content of free and bound phenolics (A) and flavonoids (B) under two cultivation and during two growing seasons

The total phenolics and total flavonoids content in both growing seasons was higher in the soybean grains obtained from the conventional system. It can be possibly related to higher plant stress in conventionally produced grains caused by application of pesticide imazamox. The obtained content for total phenolics was $2-3$ times higher than that for the Portuguese soybean cultivar grains (1360 mg kg-1 GAE) (Teixeira-Guedes et al., 2019), but in line with the results recorded for the methanolic extracts of some other Serbian soybean cultivars seeds (2228$3255 \mathrm{mg} \mathrm{kg}^{-1} \mathrm{QE}$ ) (Prvulović et al., 2016). However, the content of total flavonoids in examined grains was lower compared with that of other Serbian soybean cultivars (601-1475 mg kg-1 QE) (Prvulović et al., 2016).

Table 3. Pearson's correlation coefficient $(r)$ for the level of agreement between two cultivation systems and during two growing seasons

\begin{tabular}{|c|c|c|c|c|}
\hline & Organic 2016 & Conventional 2016 & Organic 2017 & Conventional 2017 \\
\hline Organic 2016 & 1 & $0.995 *$ & $0.893 *$ & $0.933 *$ \\
\hline Conventional 2016 & & 1 & $0.931 *$ & $0.960 *$ \\
\hline Organic 2017 & & & 1 & $0.991 *$ \\
\hline Conventional 2017 & & & & 1 \\
\hline
\end{tabular}

*-significant at $p<0.05$ 
Antioxidant activity. The results for the ability of analysed extracts to quench $\mathrm{ABTS}^{++}$radicals proved a significant potential for this process $(27.6-38.2 \%$ of scavenging capacity) (Fig. 3).
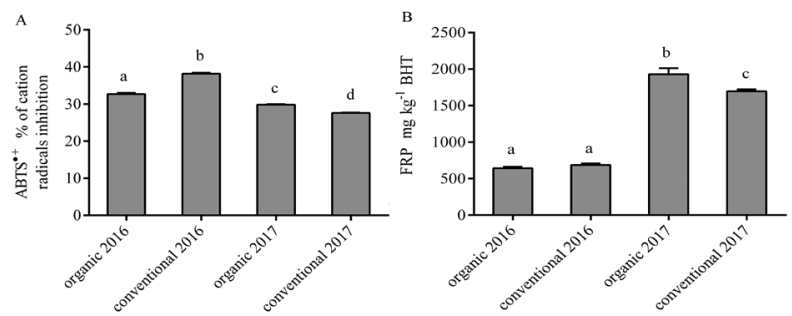

Note. The different case letters indicate the significant difference $(p<0.05)$ between samples according to Tukey's test $(\mathrm{n}=3)$; BHT - butylated hydroxytoluene.

Figure 3. $\mathrm{ABTS}^{+}$scavenging capacity (A) and ferric reducing power (FRP) (B) assays for soybean grains

Both the highest and the lowest quenching radical abilities were recorded for conventionally produced grains. All obtained data for $\mathrm{ABTS}^{*+}$ scavenging capacity were significantly different according to Tuckey's test $(p<0.05)$. Results of $\mathrm{ABTS}^{+}$assay are comparable to (growing season 2016) or lower (growing season $2017)$ than the results for $0.2 \mathrm{mg} \mathrm{mL}^{-1}$ extract $(\sim 40 \%$ of scavenging capacity) of Grewia carpinifolia, tropical vegetable plant (Adebiyi et al., 2017).

Interestingly, the results of FRP assay (Fig. 3) were contrary to the results for $\mathrm{ABTS}^{++}$assay, since the soybean grains from 2017 displayed a significantly higher ability to reduce $\mathrm{Fe}^{3+}$ compared to that from 2016. The observed contradiction might be related to different mechanisms of the applied assays. Namely, the FRP assay belongs to the single electron transfer-based antioxidant methods, while the $\mathrm{ABTS}^{\cdot+}$ assay, beside this, also includes hydrogen atom transfer during the reaction of some molecules with radical ions (Sun et al., 2018).

Correlation analysis revealed strong positive relationship between the ability of soybean grains to quench $\mathrm{ABTS}^{-+}$radicals and the content of free phenolics $(r=0.909)$ as well as the content of all sugar fractions $(r=0.924-0.991)$ except starch. The obtained results are expected since plant phenolics and reducing sugars are important antioxidants (Dai, Mumper, 2010; Keunen et al., 2013). Results for FRP assay, exhibited strong positive correlation for free phenolics $(r=0.954)$ as well as reducing $(r=0.945)$ and non-reducing $(r=0.937)$ disaccharides. This indicates that phenolic fraction and disaccharides are the main electron transporters in soybean grains.

\section{Conclusions}

1. According to the obtained results, the grains of the soybean cultivar 'Kaća', developed and grown in Serbia under conventional and organic cultivation systems, exhibited lower content of total lipids compared to the literature data. The results of high-performance liquid chromatography (HPLC) analysis showed the prevalence of unsaturated fatty acids with linoleic and oleic acids as the main components. Based on the results of HPLC method for the content of triacylglycerols (TAGs), the presence of the ensuing TAGs was recorded: TAGs with 44 (ECN 44) as well as with 46 (ECN46) equivalent carbon numbers were predominant fractions followed by ECN42, ECN48 and ECN50.

2. The analysed grains were characterized by the low content of total sugars and starch. Among the identified fractions of individual sugars, it was determined that non-reducing sugars (most likely sucrose) were dominant components. The obtained results proved that soybean grains are a good source of phenolics compounds. According to the results of $\mathrm{ABTS}^{\cdot+}$ assay, bioactive compounds from soybean grains are good quenchers of free radicals. Statistical analysis of the content of sugars has shown significant differences between the organically and conventionally produced grains as well as between the growing seasons.

3. The differences between total phenolics content were observed for applied growing systems as well as for antioxidant assays. The obtained results point out the importance of growing conditions for the biosynthesis of some primary and secondary plant metabolites. Strong positive correlations and results of Bland-Altman plot analysis revealed that for most of the monitored parameters there were no significant differences between both cultivation systems and growing seasons. The soluble sugars and starch content differed between the organically and conventionally produced grains. Also, significant differences were observed during the two growing years for the content of monounsaturated fatty acids (organic system), the content of soluble sugars (conventional system) and the content of oleic acid (both cultivation systems).

\section{Acknowledgements}

The authors are thankful to the Ministry of Education, Science and Technological Development of the Republic of Serbia for financial support through contract No. 451-03-68/2020-14/200116.

Received 14032020

Accepted 19102020

\section{References}

Adebiyi O. E., Olayemi F. O., Ning-Hua T., Guang-Zhi Z. 2017. In vitro antioxidant activity, total phenolic and flavonoid contents of ethanol extract of stem and leaf of Grewia carpinifolia. Beni Suef University Journal of Basic and Annlied Sciences, 6 (1): 1010-1014. https://doi.org/10.1016/j.bjbas.2016.12.003

Aguirrezabai L., Martre P., Pereyra-Irujo G. Echarte M. M. Izquierdo N.' 2015. Improving grain quality: ecophysiological and modeling tools to develop management and breeding strategies. Sadras V. O., Calderini D. F (eds.). Crop physiology (2nd ed) Flevier The Netherlands chanter 17 n $423-465$. https://doi.org/10.1016/B978-0-12-417104-6.00017-0

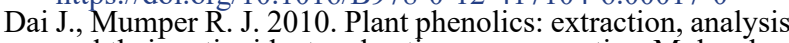
and their antioxidant and anticancer properties. Molecules, $15(10) \cdot 7313-7352$ https://doi.org/10.3390/molecules 15107313

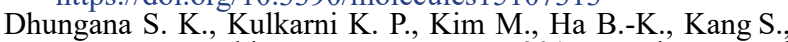
Song J. T., Shin D.-H., Lee J.-D. 2017. Environmental stability and correlation of soybean seed starch with protein and oil contents. Plant Breeding and Biotechnology, 5: 293-303. https://doi.org/10.9787/PBB.2017.5.4.293

Dornbos Jr. D. L., Muilien K. E. i i $\bar{y} \bar{z}$. Soybean seed protein and oil contents and fatty acid composition adjustments by drought and temperature. Iournal of the American Oil Chemists Society, 69 : 228-231. https://doi.org/10.1007/BF02635891

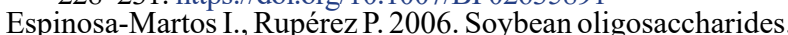
Potential as new ingredients in functional food. Nutricion Hospitalaria, 21 (1): 92-96. http://digital.csic.es/ bitstream/10261/1652/1/espinosa.pdf

Frølund B., Palmgren R., Keiding K., Nilsen H. 1996. Extraction of extracellular polymers from activated sludge using a cation exchange resin. Water Research, 30 (8): 1749-1758. https://doi.org/10.1016/0043-1

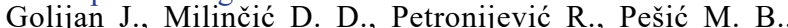
Barać M. B., Sečanski M., Lekić S., Kostić A. Ž. 2019. The fatty acid and triacylglycerol profiles of conventionally and organically produced grains of maize, spelt and buckwheat Inurnal of Cereal Science $90 \cdot 102845$. https://doi.org/10.1016/j.jcs.2019.102845

Hou A., C'hen Y.., Shi A., Zhang B. B., Wang Y..-J. 2009 (a). Sugar variation in soybean seed assessed with a rapid extraction and quantification method. International Journal of A gronomy 2009: ID 484571. https://doi.org/10.1155/2009/484571

Hou A., Chen P., Ailioatti J. J., Li Ī., Miazzoni L., Zhang B., Shi A 2009 (b). Genetic variability of seed sugar content in worldwide soyhean rermplasm collections. Cron Science, 49 (3): 903-912. https://doi.org/10.2135/cropsci2008.05.0256

Jahaniaval F., Kakuda Y., Marcone M. F. 2UUU. Fatty acid and triacylglycerol compositions of seed oils of five Amaranthus accessions and their comparison to other oils. Journal of the American Qil Chemists' Society, 77: 847 https://doi.org/10.1007/s11746-000-0135-0 
Jokić S., Zeković Z., Vidović S., Sudar R., Nemet I., Bilić M., Velić D. 2010. Supercritical $\mathrm{CO}_{2}$ extraction of soybean oil: process optimisation and triacylglycerol composition. International Journal of Food Science and Technology, 45 (9): 1939-1946. https://doi.org/10.1111/j.1365-2621.2010.02358.x

Keunen E., Pesiev $\bar{D}$., Vangronsveid J̄., Van Den Ënde W. Cuypers A. 2013. Plant sugars are crucial players in the oxidative challenge during abiotic stress: extending and traditional concent. Plant, Cel1 and Environment, 36 (7): 1242-1255. https://doi.org/10.1111/pce.12061

Kim S. L., Lee J. E., Kwon Y. Ü., Kim W. H., Jung G. H. Kim D. W., Lee C. K., Lee Y. Y., Kim M. J., Kim Y. H. 2013. Introduction and nutritional evaluation of germinated sov germ. Fond Chemictry $136(2): 401-500$. https://doi.org/10.1016/j.foodchem.2012.08.022

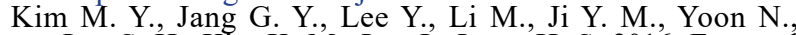
Lee S. H., Kim K. M., Lee J., Jeong H. S. 2016. Free and bound form bioactive compound profiles in germinated black soybean (Glycine max I.). Fond Science and Bintechnology, 25: 1551-1559. https://doi.org/10.1007/s10068-016-0240-2

Kováčová M., Malınová E. Żं̄ \% Ferulic and coumaric acids, total phenolic compounds and their correlation in selected oat genotynes. Czech Inurnal of Fond Sciences, 25: 325332. https://doi.org/10.17221/746-CJFS

Kresović B̄. A., Gajic B. A., Iapanarova A., Dugalić G. 2017. Yield and chemical composition of soybean seed under different irrigation regimes in the Vojvodina region. Plant, Soil and Environment, 63: 34-30 https://doi.org/10.17221/673/2016-PSE

Laware S. L.. ZUं IJ. Sequentiai extraction of plant metabolites. International Journal of Current Microbiology and Applied Sciences, 4 (2): 33-38. https://www.ijcmas.com/vol-4-2/ Shankar\%20L.\%20Laware.pdf

Lin L.-Z., Harnly J. M. 2007. A screening method for the identification of glycosylated flavonoids and other phenolic compounds using a standard analytical approach for all plant materials. Journal of $\Delta$ griculture and Food Chemistry, 55 (4): 1084-1096. https://doi.org/10.1021/jf062431s

Liu K. 1997. Soybeans - Ćnemistry, Iechnology and Útilization. Springer, $76 \mathrm{p}$.

Peiretti P. G., Karamać M., Janiak M., Longato E., Meineri G. Amarowicz R., Gai F. 2019. Phenolic composition and antioxidant activities of soybean (Glycine max (L.) Merr.) plant during growth cycle. A gronomy, 9 (3): 153. https://doi.org/10.3390/agronomy9030153

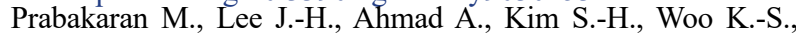
Kim M.-J., Chung I.-M. 2018. Effect of storage time and temperature on phenolic compounds of soybean (Glycine max I.) flour. Molecules, 23 (9): 2269 https://doi.org/10.3390/molecules23102713

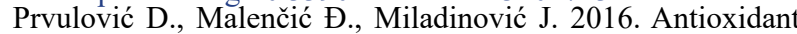
activity and phenolic content of soybean seeds extracts. $\Delta$ gro-knoweledge Inurnal, 17 (2): 121-132. https://doi.org/10.7251/AGREN1602121P
Rembialkowska E. 2007. Quality of plant products from organic agriculture (review). Journal of the Science of Food and Arriculture, 87 (15): 2757-2762. https://doi.org/ $10.1002 /$ jsfa. 3000

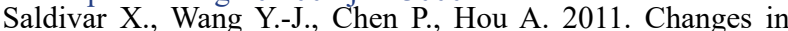
chemical composition during soybean seed development. Fond Chemictry 124 (4): 13\%9-1375 https://doi.org/10.1016/j.foodchem 2010.0

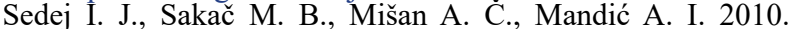
Antioxidant activity of wheat and buckwheat flours. Proceedings for Natural Sciences Matica Srnska, Novi Sad, 118: 59-68. https://doi.org/10.2298/ZMSPN1018059S

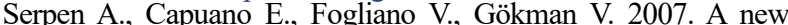
procedure to measure the antioxidant activity of insoluble food components. Journal of A griculture and Fond Chemistry, 55 (19): 7676-7681. https://doi.org/10.1021/jf071291z

Singleton V. L., Orthoter K., Lamuela-Kaventos K. M. 1999. Analysis of total phenols and other oxidation substrates and antioxidants by means of Folin-Ciocalteu reagent. Methods in Enzymology, 200: 152-178 https://doi.org/10.1016/S0076-6879(99)99017-1

Stevenson D., Doorenbos K. K., Jane J.-L., Ingiett G. E. 2006. Structures and functional properties of starch from seeds of three soybean (Glycine mox (I.) Merr) varieties. Starch, 58 (10): 509-519. https://doi.org/10.1002/star.200600534

Sudarić A., Matoša Kočar M., Duvnjak I., Ldunic Z. Markulj Kulundžić A. 2019. Improving seed quality of sovbean suitable for growing in Europe. Intech Open. https://doi.org/10.5772/intechopen.89922

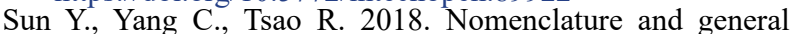
classification of antioxidant activity/capacity assays. Apak R. et al. (eds). Measurement of Antioxidant Activity and Capacity: Recent Trends and Annlications. Wilev, chapter 1, p. 1-21. https://doi.org/10.1002/9781119135388.ch1

Teixeira-Guedes C. 1., Uppolozer D., Barros A. 1., PereiraWilson C. 2019. Impact of cooking method on phenolic composition and antioxidant potential of four varieties of Phaseolus vulgaris L. and Glycine max L. LWT-Food Science and Technology, 103: 238-246 https://doi.org/10.1016/j.lwt.2019.01.010

Wijewardana $\overline{\mathrm{B}}$., Keddy $\overline{\mathrm{K}}$. K., Beiliaioui $\overline{\mathrm{N}}$. 2019 . Soybean seed physiology, quality, and chemical composition under soil moisture stress. Food Chemistry, 278: 02-10n. https://doi.org/10.1016/j.foodchem.2018.11.035

WRB, 2U14. World reference base for soil resources. World Soil Resources Reports No. 106. FAO, 189 p.

Žilić S., Gül Akilhoğlu H., Serpen A., Perić V., Gökmen V. 2015. Comparisons of phenolic compounds, isoflavones, antioxidant capacity and oxidative enzymes in yellow and black soybeans seed coat and dehulled bean. European Food Research and Technology, 237: 400-418. https://doi.org/10.1007/s00217-013-2005-y

\title{
Ekologiškai ir tradiciškai užaugintų Serbijoje gauruotosios sojos sẻklų cukrų, lipidų ir fenolių kiekiai
}

\author{
J. M. Golijan1, D. D. Milinčić1 , R. B. Petronijević², M. B. Pešić1 , S. P. Stanojević1,
} M. B. Barać ${ }^{1}$, S. Lekić ${ }^{1}$, A. Ž. Kostić1

${ }^{1}$ Belgrado universiteto Žemès ūkio fakultetas, Serbija

${ }^{2}$ Mèsos higienos ir technologijos institutas, Serbija

\section{Santrauka}

Tyrimo tikslas - nustatyti gauruotosios sojos (Glycine $\max ($ L.) Merr.) veislès 'Kaća' sèklu pirminiu metabolitu: mono- bei disacharidų, tirpiụjų cukrų, krakmolo, lipidų, riebalų rūgščių, triacilglicerolių, ir antrinių metabolitų: fenolių ir flavonoidị, kiekį. Be to, sėklų antioksidacinės savybės buvo ịvertintos taikant $\mathrm{ABTS}^{++}$radikalų surišimo ir geležies jonų redukcijos (FRP) metodus. Sojos buvo augintos Serbijoje tradicinės ir ekologinès žemdirbystès metodais du vegetacijos sezonus (2016 ir $2017 \mathrm{~m}$.). Abiem vegetacijos sezonais ir taikant abi auginimo sistemas veislès 'Kaća' soju sèklose lipidai sudare $8,2-14,3 \%$, iš riebalu rūgščiu polinesočiosios riebalu rūgštys sudarẻ 50,3-57,9\%. Pagrindinę dalị triacilglicerolių (30,9-32,8 \%) sudarè ECN44 frakcija. Suminio tirpiojo cukraus kiekis buvo nedidelis $(2,4-11,5 \%)$. Taikant didelio efektyvumo skysčių chromatografiją (HPLC) nustatytas reikšmingas neredukuojančių disacharidų (1,41-6,57\%) dominavimas tarp cukrų; fenoliu kiekis buvo $2494-4420 \mathrm{mg} \mathrm{kg}^{-1}$, flavonoidu - 292,7-500,9 mg kg-1, iš kuriu dominavo nesurištos frakcijos. Nustatyta stipri teigiama koreliacija tarp auginimo sistemų ir tyrimo metų; tai rodo, kad pagal šiuos veiksnius sėklose nustatyti metabolitų kiekiai reikšmingiau nesiskyrè. Palyginus su 2016 m., 2017 m. derliaus sojų sėklų ekstraktai gebėjo reikšmingai stipriau neutralizuoti $\mathrm{ABTS}^{++}$radikalus ir redukuoti geležies jonus $\left(\mathrm{Fe}^{3+}\right)$.

Reikšminiai žodžiai: antioksidacinis aktyvumas, cukrūs, fenoliniai junginiai, Glicine max, riebalų rūgštys, triacilgliceroliai. 